\title{
Richard III: A Villain or a Victim?
}

\author{
Assoc. Prof. Petraq Buka
}

Department of English, Faculty of Foreign Languages, Tirana University, Albania

\section{Doi:10.5901/ajis.2014.v3n6p353}

\begin{abstract}
This article seeks to give some insight on the controversial figure of Richard III of England. He is known as probably the most maligned monarch in British history and he has come down in history as the man who cleared his way to the throne by eliminating his rivals. He is mostly reviled for murdering his young nephews in the Tower of London. His supporters, however, argue that King Richard is the victim of a smear campaign by the Tudors, who ascended the throne after the death of Richard III in the Battle of Bosworth. They claim that king Richard has been vilified and his reputation has been blackened by Tudor propaganda, as history is written by the victors. Richard III was a typical ruler of his time. He has to be measured by the standards of his time. After 500 years of speculations about the figure of Richard III, there is hope that a wronged monarch might at last find posthumous justice. It proves that it is never too late to save one's reputation.
\end{abstract}

Keywords: Usurp, maligned, villain, hunchback, tyrant, rehabilitate

\section{Introduction}

King Richard III is one of England's most controversial historical figures. He is probably the most hated monarch in English history. Few monarchs have seen their reputations decline as much after death as Richard III. He ruled England between 1483 and 1485, during the last two years of the 30 year Wars of the Roses between the Houses of York and the House of Lancaster. He was king of England, but for centuries he lay without shroud or coffin in an unknown grave, and his name became a synonym for villainy. After his death at 32 years of age, Richard was accused of numerous crimes most infamously, the murder of his two nephews in the Tower of London.

The location of Richard's body was unknown for centuries. He was killed in 1485 at the Battle of Bosworth Field in the English Midlands, and records say he was buried by the Franciscan monks of Grey Friars at their church in Leicester. An archaeological team from Leicester University pinpointed the site of the ancient Grey Friars church, where Richard was believed to have been buried after being killed in the Battle of Bosworth in August 1485, and which was razed to the ground in 1538 during the Dissolution of the Monasteries ordered by Henry VIII.

In August 1913, the team of scientists announced that the skeleton unearthed under a municipal parking lot in Leicester was "beyond reasonable doubt" that of the 15th-century king, Richard III of England. The results of DNA revealed that the bones discovered belonged to Richard III. A forensic reconstruction of King Richard's face was made and it greatly resembles paintings made of Richard in the years shortly after his death.

The news that the remains of King Richard III have been found should finally end 500 years of speculation about King Richard III. His short reign can be viewed with a more objective eye, based on the facts instead of the mere propaganda of the time.

The real argument with the skeleton had to do with Richard's status as a deformed man and a hated historical king. With the latest discovery, it appears that England's most maligned king may get a redemption. Richard's supporters hope that the old Shakespearean prejudices will be submitted to an honest scrutiny, in the hope that Shakespeare's work on Richard III can be dismissed as little more than myth.

***

Old tales of plots and royal murder are fertile breeding grounds for passionate controversy. All the more so because in this case there is very little solid information: the imagination is free to rearrange and re-interpret the few bare facts that have come down from contemporary sources. History is written by the victors. When the Tudors defeated and succeeded the Yorkist king, they blamed him for all the country's ills. Richard was the target of a smear campaign orchestrated by the Tudor dynasty, whose founder Henry VII defeated Richard, in 1485. Tudor historians deliberately blackened Richard's character, and Shakespeare followed suit by putting a hunchbacked tyrant on stage. Rightly or wrongly, Richard went down in history as a murderous tyrant, a ruler who embodied the worst late-medieval vices and 
character. Many historians, however, claim that his reputation is unjust and was fabricated by Tudor propaganda before being cemented by Shakespeare.

The Tudors were the first to understand that in the long-term people will remember what is written. Among the first acts of Henry VII was to portray Richard as an evil usurper who the Tudors defeated in a glorious battle. Writers and historians continued the trend. Thomas More, the renowned humanist of the time, attributed Richard's physical deformities to an "evil mind". The portrayal culminated in Shakespeare's famous play which sealed Richard's image for centuries to come.

Henry Tudor himself had only a shaky claim to legitimacy and lived in perpetual fear of conspiracy and revolt. He strengthened his claim to the throne by his marriage to Elizabeth of York, the eldest daughter of Edward IV, i.e. the niece of Richard III. His emblem, the Tudor Rose, was a symbol of the union of the two warring houses, the Lancastrians and the Yorkists. To justify the seizure of power, the Tudor dynasty had to portray Richard as a monster. The Tudor picture of Richard as a bloodthirsty tyrant has been handed down through the history books and the school textbooks for five centuries.

Shakespeare is responsible more than any other person for the popular image of Richard as a murderous hunchback. Richard III has been immortalised by Shakespeare in his play The Tragedy of Richard III as the King who murdered his way to the throne. He is depicted as a monster and a hideous creature and as everyone knows from Shakespeare, he is the most durable villain that ever appeared on the English stage. Shakespeare's play depicts Richard murdering his nephews, the sons of Edward IV, in their beds as part of a vicious and merciless plot to clear his path to the throne. In the course of his very short rule, Richard commits several bloody acts and the circle of his crimes is only broken when he is slain in the Battle of Bosworth by Henry Tudor.

Shakespeare's sources for his brilliant play were Tudor chroniclers and historians, most notably Sir Thomas More. Drawing on biased historical accounts like Thomas More History of King Richard III (1519), Shakespeare's Richard is a limping hunchback with a withered arm, as deformed in appearance as he was in character. Richard is also depicted with an unnaturally raised shoulder. This is a version of events calculated to legitimise the reign of the founding Tudor Henry VII.

"Shall I be plain? I wish the bastards dead," says Richard in the play. Yet the evidence for their murders is at best circumstantial, and at worst pure Tudor invention. Shakespeare even has Richard killing the Duke of Somerset at the battle of St. Albans, which took place when Richard was two years old. Shakespeare even has Richard say: "I am determined to prove a villain." Who in his right mind would ever say that, especially if it were true?

"Since I cannot prove a lover/l am determined to prove a villain," Richard says. Shakespeare's dramatic work does not aim to dispel myths, but rather to give them life. Long before Richard's bones were exhumed and his identity proven, Shakespeare had already revealed the essence of his character in the contradictory idea: "Is there a murderer here?" (No/Yes).

Both Sir Thomas More and William Shakespeare portrayed King Richard III as a monster. But, one must keep in mind that these men wrote to please the Tudors. They weren't writing an unbiased historical account of his life. Shakespeare was a dramatist, not a historian, and as for Thomas More, he was a close friend to King Henry VIII, so it only makes sense that he would want to portray his father's enemy as an evil, usurping king.

***

Richard was said to be short and dark, like his father, quite unlike his blond brother, King Edward IV. The surviving portraits of him show a reasonably handsome face. In most of the portraits he is toying with a ring on one of his fingers. One of the few things that seem certain about Richard is that he was not deformed. The hunchback, the withered arm, that malignant face were all inventions of Tudor propaganda.

No portrait of Richard III survives from his lifetime. However, the in an early copy from 1510, Richard has no deformity whatsoever. Most surviving portraits of Richard come from the late 16th century, when the fashion in great halls across the nation was to display a set of images of each English monarch chronologically. These were produced cheaply in workshops, and based on a pre-established likeness: in Richard's case, Richard has uneven shoulders, thin lips and narrow eyes.

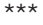

In fact, who was Richard III? Was he a villain or a victim? It is a question that historians have argued about for centuries. Was he an evil, child killing murderer than would stop at nothing to claim the throne of England? Or was he loyal to his brother, Edward IV, and only accepted the crown with great reluctance when he believed that the young 
princes were illegitimate? Unfortunately, none of those questions has been answered conclusively. No one knows for sure if Richard III is the monster depicted in Shakespeare's famous play and if he really killed his young nephews and usurp the throne. For centuries historians have struggled to put forward a different version of history.

In truth, there is no firm evidence pointing at Richard for any of these events. There is evidence, however, that shows that Richard was loyal to his older brother, Edward IV, and that Richard fought bravely by his side in numerous battles and even fled into exile with him. Then when Edward claimed the crown, Richard controlled the north of England with great skill and competence and was very well respected by the people.

Richard III started his kingship as a popular monarch. Richard was depicted by contemporary sources as a man of virtue and honour. As President of the Council of the North, he greatly improved conditions of people of the region. He was regarded as a just and capable ruler whose actions benefited the common people. King Richard introduced the idea of "blind justice", whereby all men should be treated the same under the law. There would be no preference to someone of noble birth, and both peasants and noblemen were to be afforded the same rights under the law. Another idea of his was the presumption of innocence for the accused: innocent until proven guilty. He also wanted the laws of the land written in English, so even poor men would understand their rights.

A man of literacy himself, he banned restrictions on the printing and sale of books, and ordered the translation of the written laws and statutes from French (the traditional language of the law) into English so that common people would understand it. Richard III abolished press censorship, invented the right to bail for people awaiting trial, reformed the country's finances. These ideas no doubt contributed to his loss of popularity among the nobles in England. They were used to favouritism under the law, and they saw the new laws as a grave threat to themselves and their way of life. That this may have contributed to his ultimate downfall, since he lost the support of many of the nobles during his reign.

***

Demonization began soon after Richard's death by the historian John Rous. During the King's lifetime, John Rous praised him as a "mighty prince and good lord", who punished "oppressors of the commons". But after Richard's death he took it all back. Keen to ingratiate himself with Henry VII, he portrayed Richard as an anti-Christ: born with "fully grown teeth and hair, as well as uneven shoulders, the right higher [than] the left".

The turning point of Richard's character appears to be his brother's death. Edward IV named his trusted brother guardian and Lord Protector of his young sons. Richard was named Lord Protector till young king, Edward, came of age. Richard sent Edward V and his younger brother, Richard, to the Tower, which was a royal residence and the place where English Monarchs traditionally prepared for their coronations.

A clergyman informed the Lord Protector that prior to marrying Elizabeth Woodville, Edward IV had already promised to marry one Eleanor Butler (and in those times, a promise of marriage equalled actual marriage). Since Eleanor Butler was alive at the time of Edward's marriage to Elizabeth Woodville, that made their union invalid and their children - including Edward V, illegitimate. When first doubts about the legitimacy of Edward IV's children surfaced, Richard seized the chance. Soon after, the Parliament invalidated the marriage of Edward IV and Elizabeth Woodville, and proclaimed that since their children were illegitimate, they were barred from the Throne. Richard of Gloucester was now the sole rightful heir of Edward IV. He was proclaimed King and he ascended the throne as Richard III.

The usurpation is actually not very difficult to explain. The fact is that a 12-year-old was not prepared to Kingship. Child Kings never succeeded in England; in fact, the War of Roses started because of a child King, Henry VI. The country was just recuperating from the bloody and lengthy civil war, and no one wanted Lancastrians to resume the throne because of a weak king. Subjects in 15th-century England wanted a strong ruler who could give them order and stability and save them from the horrors of civil wars like those of the Wars of the Roses.

These events certainly don't seem to fit with Richard's previous character and actions. What made him betray the nephews he had sworn to protect and whom he was deeply attached to? Richard was warned that if the Woodvilles got the young king crowned they would take everything. One of the first things Richard did was to ensure the relatives of the new King's mother, the Woodvilles, were stripped of all their powers. It was feared that Edward V's reign would enhance the influence for the Woodville family, which was viewed as using their royal connections to their advantage. This fear antagonised the old nobility and the House of Commons against the entire Woodville family. It is therefore understandable why Richard met so little resistance when he prevented the unpopular Woodville family from gaining any influence.

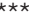

But some historians insist there is no evidence to support the story and claim that the fate of the two princes remains a mystery to this day. They have insisted that Richard was not getting a fair treatment, that the Tudor version was largely a fabrication: far from being a monster, Richard was a noble, courageous, tender-hearted and most 
conscientious king. Richard III was a formidable fighter and certainly not the weak hunchback Tudor propaganda depicted him as.

King Richard was determined to end the battle in Bosworth Field there and then: he declared that "This day I will die as a King or win". Richard led a cavalry charge deep into the enemy ranks in an attempt to end the battle quickly by striking at Henry Tudor himself. His battle axe held high, with only a few men around him, he managed to kill Henry's standard bearer and was about to kill his rival, Henry Tudor, when he was surrounded and slaughtered in the thick of fierce fighting. It is said that his final words were "Treason! Treason!". He was the second (after Harold, in 1066) and last English king to die in battle. Richard's body was taken to Leicester where it was hastily buried under the altar of Grey Friars Church there.

***

What happened to the Princes in the Tower is not known. They certainly disappeared at the time of Richard's reign. Did they die of natural causes (there was another epidemic of plague at the time)? Did he order them to be killed, as is most commonly assumed? Or did others make sure the boys will never be seen again? Certainly, Henry Tudor desperately needed them dead for even if he was the one who defeated Richard III, the Princes, if alive, would have far more rights to the Throne than he or his wife. None of those questions were ever answered.

They were seen playing and practicing archery on the grounds and were seen staring out of windows. Then they were seen less and less often, and after about the month of August they were not seen at all. According to Tudor historians, Richard had them strangled in their beds. A DNA test on the bones found in a chest under a stairway in the Tower in the late 17th century might establish whether they are the royal children, but it wouldn't tell us how they died.

Truth about Richard III is hard to decipher after all these centuries. He was brave and clever, an able ruler and commander. Was he also a wicked person, a villain and a heartless killer of innocent children? That is open to debate. Even if he was all that, that simply made Richard a man of his time. A deposed king was usually a dead king. Edward II of England was killed on the orders of his wife Isabelle and her lover Roger Mortimer. Richard II was either killed or left to die of starvation on the orders of the usurper Henry IV. Henry VI died in the Tower more likely on the orders of his Yorkist cousin, Edward IV.

Not merely Richard III, but also his successor Henry VII needed the princes out of the way. It is known that Henry became highly perturbed throughout his reign whenever pretenders appeared, claiming to be the princes. This implies that he suspected that they might still have been alive at the time of Bosworth. Indeed, the "good" Henry VII had more blood on his hands than Richard: he never hesitated to dispose of anyone he viewed as a potential threat, no matter how

young or old they were. That trait seems to have been inherited by his son, Henry VIII.

Most people think of Richard III as a hunch-backed monster who murdered his own nephews to usurp the throne. A lot has been written about this much maligned king, until recently, when the Richard III Society, brought new facts to light. The Richard III Society, since 1924, has dedicated itself to promoting a rehabilitated Richard. Members of the group raised $\$ 250,000$ to support the search for Richard's grave and his genetic testing. As one organizer told the New York Times, "Now we can rebury him with honour, and we can rebury him as a king."

The existence of a 3,000-member society, named after him, Richard III Society, is an indication of how feelings run after 500 years. The Richard III Society is working to put up plaques and statues of their hero everywhere. On Bosworth Day, August 22, the Richard III Society puts memorial notices in newspapers. Members of this society wear Richard's badge of the White Boar on their lapels and call themselves Ricardians. Those on the other side they call anti-Richards. A member of this society threw copies of Sir Thomas More's Utopia out of his library in protest against More's shabby treatment of Richard. Ricardians and antiRichards have come to blows over a series of burning questions.

It is hoped by Ricardians that the world-wide interest in the disinterment of Richard's remains by Leicester University archaeologists will focus attention on his reputation. Just because he was killed at the Battle of Bosworth 530 years ago, it doesn't mean that a good man's name should continue to be abused. There is something uplifting in the thought that even five centuries years after his death, a wronged monarch might at last find posthumous justice. It proves that it is never too late to save one's reputation.

These days Ricardians battle to repair Richard's reputation but the traditional view is that Richard, while not as evil as Tudor historians said, was probably responsible for removing his nephews from the royal line. According to scientists at the University of Leicester, there is evidence of curvature of the spine - suggesting the unattractive quality had not been a slander by those who opposed Richard. 


\section{Conclusion}

Richard III's actions are based on current ideas of morality. The late 15th century was nothing like our age: it was an age of survival when you had to do sometimes unthinkable things to stay alive. Richard III might have been a typical ruler of his time. His violence was understandable given the times. The Richard III Society may be correct in asserting that Richard was vilified without substantial proof. It is likely that much of the evidence that would prove or disprove Richard's rotten reputation has been lost.

Richard, like any one else, has to be measured by the standards of his time and place. Richard came to manhood in the anarchic times known as the Wars of the Roses fought between the rival houses of Lancaster and York. These wars were fought with the goal of getting possession of more land, which was almost the only source of money and power in those days. By the time this war was over, the royal blood of England had run so thin that the Lancastrians had to strive hard to find a claimant to the throne.

The name of Richard III was darkened and dishonoured, and so it was to remain for centuries. And it still is whenever school textbooks on English history are written and Shakespeare's plays are produced. But if one visits Bosworth, up on Ambion Hill where Richard looked down on his enemies on the fateful day, one can see a battle standard of the White Boar planted by Ricardians for the faithful to rally around in their campaign against 500 years of calumny.

The burial site for the remains of Richard III has already been selected. Although Westminster Abbey and York were strong candidates (the former because Richard III was after all a King, and the latter because of the strong ties the King had with York), it now seems that Leicester Cathedral is the likeliest choice. It makes sense because King Richard spent the last 500 years in Leicester so it will be fitting for the Leicester Cathedral to be his final resting place.

\section{References}

Richard III: W. Shakespeare

Richard III: Murderer or Misunderstood?/Carol Derbyshire/2013

Richard and the Murder in the Tower/Peter A. Hancock/2011

Richard the Third/Paul Murray Kendall/2002

Richard III: The Maligned King/Annette Carson/2009

Richard III/David Baldwin/2013

Heather Nolan King Richard III: Villain Or Victim of Tudor-era propaganda? 2011

Alastair Smart/Richard III: Visions of a villain? 2013

Nick Collins: Myths of the much maligned Richard III/ 2012

Robert Wernick: Richard III, Villain or Victim? 1985

Will Grovinski: Proving a Villain: The Search for Richard III 
